\title{
Crestamento bacteriano em áster no Brasil, causado por Pseudomonas syringae pv. tabaci
}

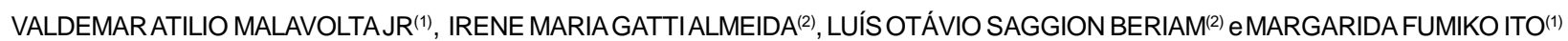

\section{RESUMO}

No ano de 2002, em plantios comerciais de áster (Aster sp.) localizados em Atibaia (SP), foram observadas plantas envasadas com lesões foliares de cor pardacenta, iniciando-se normalmente a partir dos bordos foliares, podendo atingir todo o limbo, depreciando o produto para comercialização. A partir de folhas com esses sintomas, foram isoladas bactérias caracterizadas como Pseudomonas syringae pv. tabaci. Esse é o primeiro relato dessa doença em áster no Brasil. Cultura bacteriana encontra-se depositada na Coleção de Culturas de Fitobactérias do Instituto Biológico (IBSBF) sob $\mathrm{n}^{\circ} 1662$.

Palavras-chave: doença bacteriana, etiologia, Aster sp.

\section{ABSTRACT}

Bacterial blight of aster caused by Pseudomonas syringae pv. tabaci in Brazil.

A natural occurrence of Pseudomonas syringae pv. tabaci causing leaf spot symptoms in nursery plants of Aster sp. was observed in a commercial plantation located at Atibaia, State of São Paulo, Brazil, in 2002. The pathogen was identified through biochemical, physiological, serological and pathogenicity tests. This bacterial strain was deposited at Phytobacteria Culture Collection of Instituto Biológico (IBSBF) under access number 1662.

Keywords: bacterial disease, etiology, Aster sp.

\section{INTRODUÇÃO}

Plantas envasadas de áster mostrando lesões foliares necróticas de cor pardacenta foram observadas, em plantios comerciais de áster (Aster sp.) localizados em Atibaia( SP), no ano de 2002. As manchas eram observadas inicialmente nos bordos das folhas e, com a evolução, coalesciam, podendo causar extensas áreas crestadas, depreciando e/ou inutilizando o produto para comercialização. Exames ao microscópio óptico, de tecidos com esses tipos de sintomas, revelaram a ocorrência de fluxo bacteriano. Com o objetivo de se caracterizar o agente causal da doença, foi desenvolvido o presente trabalho.

\section{MATERIALEMÉTODOS}

Isolamento - Porções de tecidos com sintomas foram macerados em água destilada esterilizada e a suspensão resultante foi semeada em placas de Petri, contendo meio nutriente agar (NA), conforme LEVINE (1954) e em meio BK (KING et al., 1954). Após 48 horas de incubação a $28^{\circ} \mathrm{C}$, as colônias bacterianas predominantes foram selecionadas, purificadas e multiplicadas para serem utilizadas nos testes de patogenicidade e de caracterização do agente causal.

Testes de patogenicidade - As inoculações foram feitas por aspersão de suspensão bacteriana (ca. $10^{8}$ ufc/ $\mathrm{mL}$ ) em mudas de áster. As plantas inoculadas foram mantidas em condições de câmara úmida por 72 horas. Nas plantas testemunhas, o inóculo foi substituído por água esterilizada.
Caracterização dos isolados - Empregaram-se testes bioquímicos, culturais e fisiológicos relacionados por BRADBURY (1986), YOUNG \& TRIGGS (1994) e por SCHAAD et al. (2001).

Testes serológicos - Suspensões bacterianas (ca. $10^{9} \mathrm{ufc} / \mathrm{mL}$ ) obtidas a partir de cultivo do isolado IBSBF*_ 1662 em meio NA $\left(48 \mathrm{~h}, 28^{\circ} \mathrm{C}\right)$, bem como proteínas do complexo protéico da membrana (CPM) foram utilizadas como antígenos. Lâminas de microscopia foram preparadas em $3 \mathrm{~mL}$ de agar a $1 \%$, em tampão fosfato salino $(0,1 \mathrm{M}, \mathrm{pH}$ 7), contendo $200 \mu \mathrm{g} / \mathrm{mL}$ de azida sódica. Os antígenos foram testados por dupla difusão em ágar, com antissoros contra isolados de P. s. pv. syringae (AS-375) e P. s. pv. tabaci (AS-761), pertencentes à Coleção de Antissoros do Laboratório de Bacteriologia Vegetal, Instituto Biológico. Tanto as suspensões bacterianas como CPM foram testados contra o soro normal, controle negativo das reações serológicas.

\section{RESULTADOS E DISCUSSÃO}

Os isolamentos efetuados mostraram, após 48-72 horas de incubação, colônias bacterianas circulares, lisas, convexas, de coloração branca a creme. As bactérias eram Gram negativas, oxidativas e produziram pigmento esverdeado, difusível em meio BK de King fluorescente sob luz ultravioleta, a $380 \mathrm{~mm}$ de comprimento de onda. Nos testes de patogenicidade efetuados no hospedeiro homólogo, os primeiros sintomas começaram a ser visualizados cinco dias após as inoculações como

\footnotetext{
(1) Instituto Agronômico, Caixa Postal 28, 13.001-970 - Campinas(SP); e-mail: malavolt@iac.sp.gov.br

(2) Instituto Biológico, Caixa Postal 70, 13001-970 - Campinas(SP).
} 
pequenas regiões anasarcadas que aumentavam de tamanho, tornavam-se escurecidas e evoluíam para necrose e crestamento foliar, reproduzindo os sintomas observados em condições naturais (figura 1). As plantas testemunhas permaneceram assintomáticas. Re-isolamentos efetuados a partir das plantas inoculadas permitiram recuperar a bactéria.

Os resultados dos testes LOPAT $\left(+---_{+}\right)$permitiram caracterizar os isolados em estudo como pertencentes à espécie Pseudomonas syringae.

De acordo com YOUNG et al. (1996), P. syringae causa doenças em um grande número de hospedeiros e essa espécie inclui mais de 50 patovares. Embora os patovares sejam determinados com base no círculo de hospedeiros, YOUNG \& TRIGGS (1994) propuseram alguns testes fisiológicos e bioquímicos que permitem diferenciar diversos patovares de $P$. syringae.

Os resultados dos testes bioquímicos, fisiológicos e culturais efetuados segundo YOUNG \& TRIGGS (1994) permitiram caracterizar os isolados obtidos como $P$. syringae pv. tabaci (tabela 1).

Segundo BRADBURY (1986), soja, fumo, feijão e ervilha são os hospedeiros mais importantes para $P$. syringae pv. tabaci, pelas perdas ocasionadas na produção. Entretanto, essa bactéria já foi descrita numa gama muito grande de hospedeiros, incluindo as recentes constatações em mamoeiro e em cafeeiro (BERIAM et al., 2006; RODRIGUES NETO et al., 2006).

De acordo com LELLIOTT et al. (1966), P. syringae pv. tabaci causa, em folhas de fumo, lesões necróticas que surgem alguns dias após a infiltração da suspensão do patógeno, provavelmente por ser o fumo seu hospedeiro natural, não se caracterizando como reação de hipersensibilidade. Entretanto, BILLING (1970) cita que reação positiva de hipersensibilidade pode ocorrer. No caso do presente trabalho, em que a bactéria foi isolada de áster, também como para o mamão e o café, foram observadas reações positivas de hipersensibilidade em fumo.

Nos testes de dupla difusão em agar, foram observadas linhas de precipitação apenas entre os antígenos e o antissoro contra $P$. syringae pv. tabaci (AS761). Todos esses resultados reforçam a identificação dos isolados de áster como P. syringae pv. tabaci.

Esse é o primeiro relato dessa bactéria ocorrendo em áster no Brasil. Cultura encontra-se depositada na Coleção de Culturas de Fitobactérias do Instituto Biológico
(IBSBF) sob n ${ }^{\circ} 1662$.

\section{REFERÊNCIAS}

BERIAM, L.O.S.; ALMEIDA, I.M.G; DESTÉFANO, S.A.L.; GRABERT, E.; BALANI, D.M.; FERREIRA, M.; RODRIGUES NETO, J. Pseudomonas syringae pv. tabaci in papaya seedlings. Summa Phytopathologica, Botucatu, v. 32, n. 1, p. 21-26, 2006.

BILLING, E. Pseudomonas viridiflava (Burkholder, 1930; Clara, 1934). Journal of Applied Bacteriology, Oxford, v. 33, p. 492-500, 1970.

BRADBURY, J.F. Guide to plant pathogenic bacteria. Kew: CAB International, 1986.332p.

KING, E.O.; WARD, M.K.; RANEY, D.E. Two simple media for the demonstration of pyocyanin and fluorescin. Journal of Laboratory and Clinical Medicine, St. Louis, v. 44, p. 301-307, 1954.

LELLIOTT, R.A.; BILLING, E.; HAYWARD, A.C. A determinative scheme for the fluorescent plant pathogenic Pseudomonads. Journal of Applied Bacteriology, Oxford, v. 29, n. 3, p. 470-489, 1966.

LEVINE, M. An introduction to laboratory technique in bacteriology. New York: The Macmillan Co., 1954. p. 68-79.

RODRIGUES NETO, J.; SILVA, C.H.D.; BERIAM, L.O.S.; PATRÍCIO, F.R.A.; RODRIGUES, L.M.R.; THOMAZIELLO, R.A. Mancha bacteriana em folhas do cafeeiro causada por Pseudomonas syringae pv. tabaci. Summa Phytopathologica, Botucatu, v. 32, supl., p. S85, 2006 (resumo).

SCHAAD, N.W.; JONES, J.B.; CHUN, N. (Ed). Laboratory guide for identification of plant pathogenic bacteria. St. Paul: APS Press, 2001. 373p.

YOUNG, J.M. \& TRIGGS, C.M. Evaluation of determinative tests for pathovars of Pseudomonas syringae van Hall 1902. Journal of Applied Bacteriology, Oxford, v.77, p.195207, 1994.

YOUNG J.M.; SADDLER, G.S.; TAKIKAWA, Y.; DE BOER, S.H.; VAUTERIN, L.; GARDAN, L.; GVOZDYAK, R.I.; STEAD, D.E. Names of plant pathogenic bacteria 18641995. Review of Plant Pathology, Palo Alto, v.75, p.721-763, 1996. 

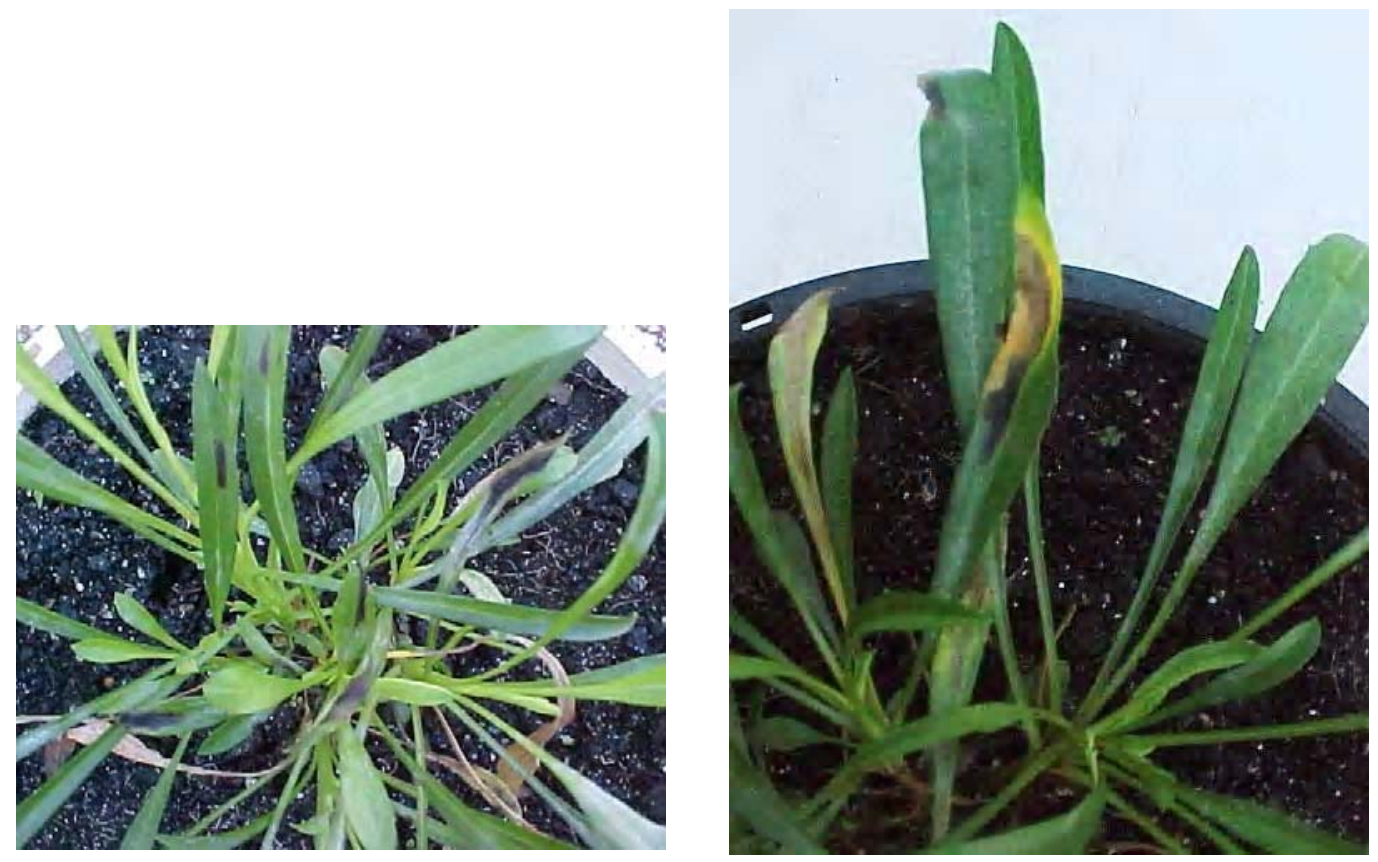

Figura 1. Sintomas causados por Pseudomonas syringae pv. tabaci em plantas de áster Figure 1. Symptoms caused by Pseudomonas syringae pv. tabaci in aster 
Tabela 1. Resultados dos testes bioquímicos das linhagens bacterianas de áster, comparados com os de Pseudomonas syringae pv. tabaci (IBSBF* 761)

Table 1. Determinative tests for the bacterial isolates of aster and for Pseudomonas syringae pv. tabaci

\begin{tabular}{|c|c|c|}
\hline Testes & Isolados de áster & Pseudomonas syringae pv. tabaci (IBSBF 761) \\
\hline $\mathrm{O} / \mathrm{F}$ & Oxid. & Oxid. \\
\hline Reação de Gram & -1 & - \\
\hline Produção de catalase & + & + \\
\hline Produção de levan & + & + \\
\hline Oxidase & - & - \\
\hline Podridão mole em batata & - & - \\
\hline Arginina dihidrolase & - & - \\
\hline Hipersensibilidade em fumo & + & + \\
\hline Redução de nitrato a nitrito & - & - \\
\hline Produção de aesculina & + & + \\
\hline Produção de indol & - & - \\
\hline Hidrólise de gelatina & + & + \\
\hline \multicolumn{3}{|l|}{ Produção de ácidos dos carbohidratos: } \\
\hline $\mathrm{L}(+)$ arabinose, eritritol, D-frutose, & + & + \\
\hline D-galactose, m-inositol, $\mathrm{D}(+)$ manose & + & + \\
\hline \multicolumn{3}{|l|}{ sacarose, $\mathrm{D}(-)$ sorbitol } \\
\hline adonitol, D(-)arabinose, & - & - \\
\hline celobiose, inulina, $\mathrm{D}(+)$ maltose & - & - \\
\hline salicina, $\mathrm{D}(+)$ trealose & + & + \\
\hline \multicolumn{3}{|c|}{$\begin{array}{l}\text { Utilização de ácidos orgânicos (sais sódicos) e } \\
\text { aminoácidos: }\end{array}$} \\
\hline gluconato, malonato, succinato & + & + \\
\hline benzoato, DL-lactato & - & - \\
\hline $\mathrm{D}(-)$ tartarato & - & - \\
\hline $\mathrm{L}(+)$ tartarato & + & + \\
\hline betaíne & + & + \\
\hline
\end{tabular}

1 + positivo; - negativo

*IBSBF= Coleção de Culturas de Fitobactérias do Instituto Biológico 